\title{
Regulation of DNA Damage Response and Homologous Recombination Repair by microRNA in Human Cells Exposed to Ionizing Radiation
}

\author{
Magdalena Szatkowska and Renata Krupa *(D) \\ Laboratory of Medical Genetics, Faculty of Biology and Environmental Protection, University of Lodz, \\ 90-236 Lodz, Poland; magdalena.szatkowska@biol.uni.lodz.pl \\ * Correspondence: renata.krupa@biol.uni.lodz.pl
}

Received: 7 May 2020; Accepted: 29 June 2020; Published: 8 July 2020

\begin{abstract}
Ionizing radiation may be of both artificial and natural origin and causes cellular damage in living organisms. Radioactive isotopes have been used significantly in cancer therapy for many years. The formation of DNA double-strand breaks (DSBs) is the most dangerous effect of ionizing radiation on the cellular level. After irradiation, cells activate a DNA damage response, the molecular path that determines the fate of the cell. As an important element of this, homologous recombination repair is a crucial pathway for the error-free repair of DNA lesions. All components of DNA damage response are regulated by specific microRNAs. MicroRNAs are single-stranded short noncoding RNAs of 20-25 nt in length. They are directly involved in the regulation of gene expression by repressing translation or by cleaving target mRNA. In the present review, we analyze the biological mechanisms by which miRNAs regulate cell response to ionizing radiation-induced double-stranded breaks with an emphasis on DNA repair by homologous recombination, and its main component, the RAD51 recombinase. On the other hand, we discuss the ability of DNA damage response proteins to launch particular miRNA expression and modulate the course of this process. A full understanding of cell response processes to radiation-induced DNA damage will allow us to develop new and more effective methods of ionizing radiation therapy for cancers, and may help to develop methods for preventing the harmful effects of ionizing radiation on healthy organisms.
\end{abstract}

Keywords: DNA damage response; double-strand DNA breaks; ionizing radiation; microRNA; cancer therapy

\section{Introduction}

Ionizing radiation (IR) consists of alpha, beta and neutron particles, as well as $\mathrm{X}$ and gamma rays. As a result of ionization, chemical reactions are initiated and they lead to major disorders of a number of cell molecules, including DNA [1-3]. Radiation-induced DNA damage initiates the signaling the transduction pathway, known as the DNA damage response (DDR), resulting in the activation of multiple cellular signaling molecules to determine the cell fate, including cell cycle arrest, apoptosis, senescence, autophagy and DNA repair $[4,5]$.

Although radiation therapy has been in use for a long time, it is one of the most effective techniques applied in the eradication of cancerous lesions in humans [6-8]. It can be used alone, as well as in combination with surgery, chemotherapy and immunotherapy. X-rays and gamma rays are photons used routinely in radiation therapy to treat various types of cancer. Particle radiation uses electron, proton and neutron beams to fight cancer. Although the majority of cancers are characterized by medium or high sensitivity to radiation therapy, those whose sensitivity is low are still a great challenge for oncologists and require the development of individualized targeted treatment methods [9,10]. 
In addition to radiosensitivity, the second problem associated with the use of radiation therapy is its high toxicity to normal tissues in the path of the radiation beam or in close proximity. Damage to healthy tissues can also be caused by radiation scattering or by low omnidirectional doses used in modern radiotherapy systems. The next category are lesions distant from the irradiation site, related to the effects of stress at the irradiation site propagated on distant parts of the body by the immune system. The destructive effect of radiation on normal cells is observed directly after radiation in the surrounding tissues and can be shifted in time, even up to several years after eradication of the tumor [9-11].

The most lethal forms of DNA damage after ionizing radiation exposure are DNA double-strand breaks DSBs) $[4,12]$. Taking into account different DNA template requirements and the available set of proteins associated with the changing of the cell cycle phase, there are two distinct DSBs repair pathways, known as canonical non-homologous end joining (C-NHEJ) and homologous recombination (HR). Each of these repair mechanisms is designed for distinct tasks and brings different results for cells $[13,14]$.

When DNA has sustained exogenous damage, the repair proteins are recruited and the cell cycle is stopped at cellular checkpoints. Unrepaired DNA lesions can inhibit transcription and induce programmed cell death to avoid mutation accumulation in the cells carrying DNA damage [15,16] Unrepaired double-strand DNA damage carried out in cancer cells is the expected end result of many therapeutic strategies, including radiotherapy, as they are lethal to the cell. Tumor cells proliferate continuously, while normal cells do so relatively rarely and most of the vital activities fall into the stationary phase. Due to the fact that the DNA repair system by homologous recombination is active only in the cell division phase, when the correct chromatid is needed for effective repair, the search for potential tumor sensitizing targets on radiotherapy in this DNA repair pathway is particularly well-founded. The concept of synthetic lethality involving homologous biologists [17-24]

MicroRNAs (miRNAs) are single-stranded short noncoding RNAs of 20-25 nt in length involved in the regulation of gene expression by repressing translation or cleaving target mRNA. More than 1000 miRNA transcription units have been identified in human genomes.

Several miRNAs, whose expression may change the regulation of DNA damage response (DDR), and HR protein components have been identified after irradiation [25-27].

This review discusses the biological mechanism through which miRNAs affect the DNA damage response and homologous recombination repair relating to IR.

\section{MicroRNA}

The biogenesis of miRNAs comprises several nuclear and subsequent cytoplasmic instances of cleavage that result in the production of mature microRNA. A primary miRNA transcript (pri-miRNA) is synthesized in two different ways, depending of the genomic location (Figure 1) [28-30]. The miRNA genes can be classified as either intergenic (miRNA-coding genes contain their own promoter and regulatory sequences) and intragenic (miRNA-coding genes are transcribed with their host genes and from a common promoter region). The intergenic miRNA genes are transcribed in pri-miRNAs and contain a 7-methylguanylate cap at the $5^{\prime}$ end and a poly(A) tail at the $3^{\prime}$ end, which are directly cleaved by Drosha and its cofactor DiGeorge critical region 8 (DGCR8), forming a double-stranded intermediate of $\sim 70$ nucleotide. On the other hand, the intragenic pri-miRNAs are cleaved by the Drosha/DGCR8 complex without affecting the splicing step. Pre-miRNA is subsequently transported by the nucleocytoplasmic transporter factor exportin-5 and ran-GTP, and in the cytoplasm, the enzyme termed DICER (RNase) converts a pre-miRNA into a miRNA duplex intermediate. One strand from a double-stranded miRNA (guide microRNA strand) is loaded onto an Argonaute 2 (AGO2) protein, while the other strand is normally degraded. The AGO2 protein is incorporated into the miRNA guide, generating an RNA-induced silencing complex (RISC) which is guided to the target mRNAs and leads to post-transcriptional gene silencing or mRNA degradation. Imperfect complementarity between miRNA and the $3^{\prime}$ untranslated region (3'UTR) of messenger RNA confers translational repression, 
whereas if the match is perfect, mRNA undergoes enzymatic cleavage. After IR exposure, significant reductions in either DICER or AGO2 have been noticed, resulting in programmed cell death.

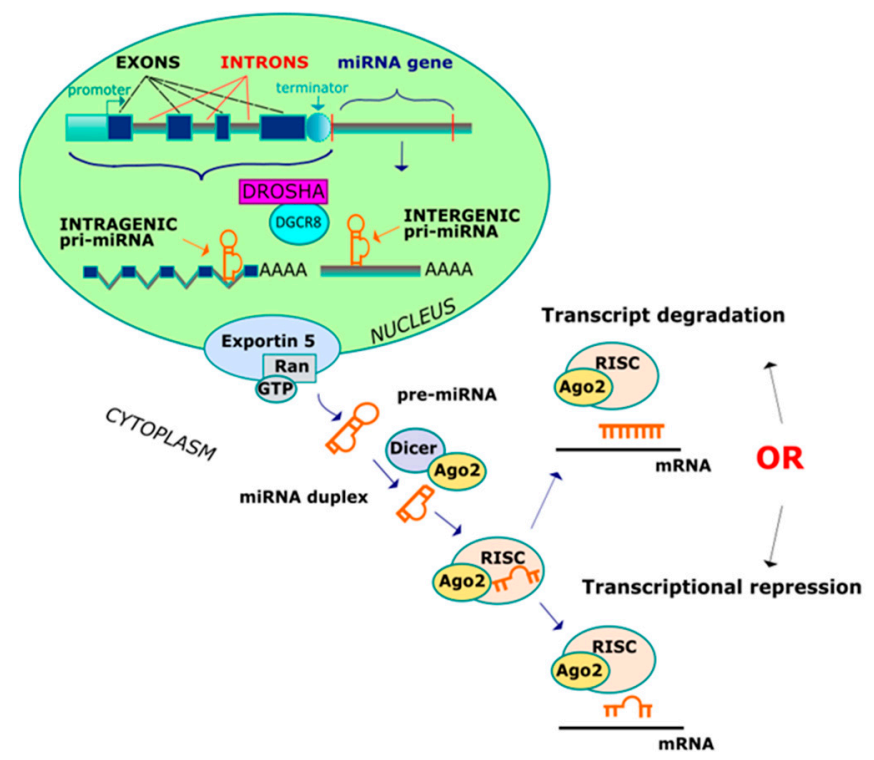

Figure 1. Two ways leading to the creation of miRNA.

MicroRNA binding sites are located in the $3^{\prime}$ untranslated region (3'UTR) of mRNA [31]. The $3^{\prime}$ UTR isoforms can play a different role in gene expression and protein synthesis. An inverse correlation was found between $3^{\prime}$ UTR length and mRNA stability, gene expression and the proliferation efficiency of cells. Short isoforms are characteristic of highly proliferative cells, including cancers. Being less liable to degradation, short isoforms are more stable and have a higher transcription and translation ability. Short isoforms contain less microRNA binding sites, which significantly increase the translational potential of mRNA $[32,33]$.

Each alternative $3^{\prime}$ UTR isoform has its own set of functional RNA-binding proteins and microRNA binding sites. The binding ability of microRNA depends on the sequence and conformation of $3^{\prime} \mathrm{UTR}$, which leads to the fact that any sequence changes that modify the conformation directly-such as mutations or polymorphisms-affect the functionality of $3^{\prime}$ UTRs. The protein level is determined by $3^{\prime}$ UTRs through the regulation of both mRNA stability and translation efficacy $[32,34]$. These tasks are based on AU-rich sequences and microRNA binding sequences [32,35-37].

The removal of AU-rich elements and miRNA-binding sites (21) from 3'UTRs of proto-oncogenes leads to the development of cancer [37,38]. See other reviews for more details [32,33].

Polymorphisms in microRNA-binding sites in the genes coding for proteins of DNA double-strand break (DSB) repair can influence the risk and prognosis of several types of cancer, including head and neck, colorectal, bladder and oropharynx [39-42].

Somatic mutations in the $3^{\prime}$ UTR sequence do not interfere with the protein sequence. They can interfere with the interaction between the microRNA and its target within the mRNA molecule by directly altering the degree of alignment with the target sequence or indirectly affecting conformation, and thus the availability of microRNA to target sites. A large-scale analysis of 67,159 somatic mutations that can alter the microRNA and mRNA interactions in 21 types of cancer demonstrated the inversed relationship between expression and microRNA-mRNA affinity levels. Functional mutations of $3^{\prime} U T R$ microRNA binding sites were more often present in the mitogen-activated protein kinase (MAPK) and WNT signaling pathways, well known to be involved in cancer development [43]. 


\section{IR Induced DNA Damage}

Gamma and $X$ rays are the most penetrating radiations and their deposition of energy can directly influence the DNA structure; however, DNA lesions may also be caused indirectly $[3,5]$. This type of radiation passes through the radiolysis of water contained in the cell and disrupts other organic molecules, which leads to the production of reactive oxygen species (ROS) and reactive nitrogen (RNS) species (Figure 2) [44]. The hydroxyl radical is the most important ROS that interacts with DNA. The hydroxyl radical generates single and double-stranded breaks in DNA by interacting with a sugar molecule in the phosphodiester chain [45-47]. It also damages the purine and pyrimidine bases, while purines are damaged with greater efficiency than pyrimidines. The frequently observed DNA base lesions are 8-oxo-7,8-dihydroguanine (8-oxoG), 2,6-diamino-4-hydroxy-5-formamidopyrimidine (Fapy-G), 8-oxo-7,8-dihydro-20-deoxyadenosine (8-oxoA) and 4,6-diamino-5-formamidopyrimidine (Fapy-A) and 5,6-dihydroxy-5,6-dihydrothymine (Thy-Gly). Ionizing radiation exposure to DNA results in apurinic/apyrimidinic sites and more than 100 different lesions $[17,48,49]$.

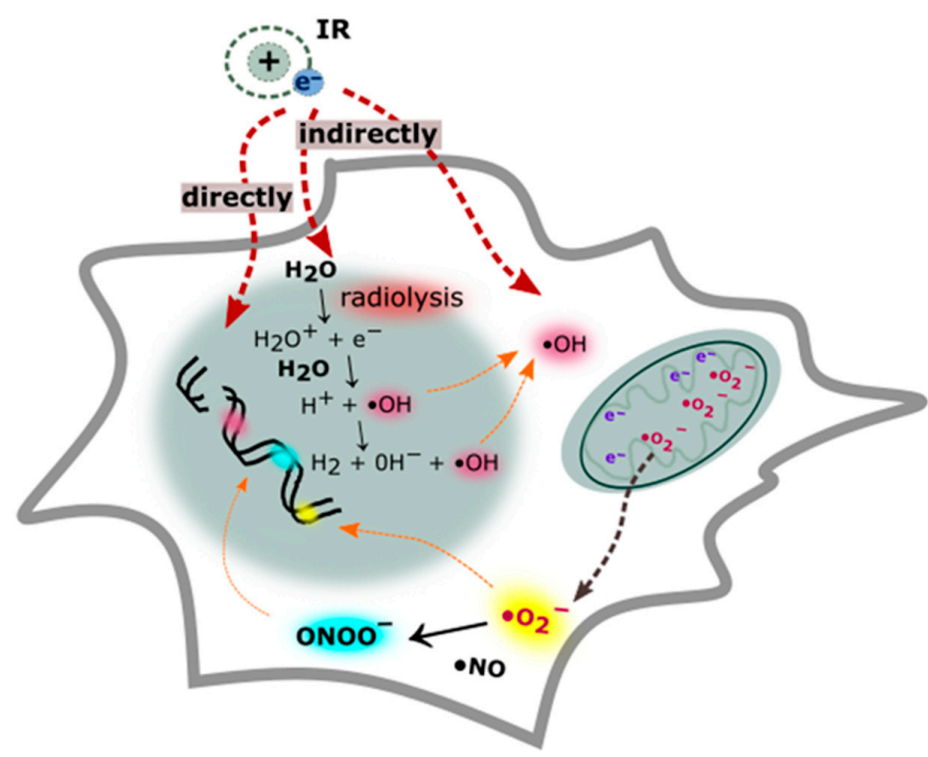

Figure 2. Direct and indirect formation of DNA damage. The absorption of ionizing radiation by living cell hits the DNA molecule directly and disrupts the chemical structure of the DNA double helix. The indirect effect of ionization depends on the radiolysis of cellular water and cellular component disruption. The removal of an electron from water leads to alterations in the nuclear and mitochondrial genome via the overproduction of reactive oxygen species (ROS) and reactive nitrogen species (RNS). During ionizing radiation (IR) exposure, large amounts of nitric oxide $(\bullet \mathrm{NO})$ are generated, which is relatively unreactive and, together with superoxide $\left(\mathrm{O}^{\bullet-}\right)$, they form a peroxynitrite anion $\left(\mathrm{ONOO}^{-}\right)-\mathrm{a}$ powerful oxidant.

The genome-wide DNA sequence preference of gamma radiation-induced double-strand DNA break formation was investigated in purified human DNA. C nucleotides-followed by G and T nucleotides-were found to be most prevalent at the cleavage site. A nucleotide was the least prevalent. This means that sequences rich in CG pairs are most exposed to DNA cleavage. The explanation of this phenomenon is conditioned by the fact that the GC base pair forms a wide, major groove in the DNA molecule, which allows the hydroxyl radical to penetrate inside the molecule and interact freely with this base pair. This observation was confirmed by various studies [50-52].

Yard et al. [53] conducted a large-scale genetic survival study on 533 genetically annotated human tumor cell lines after exposure to radiation therapy. Cancer cell survival was correlated to somatic copy number alterations. The top 19 genes that were associated with radiation sensitivity when mutated were organized by biological function. Seven of these genes, i.e., TPR18, FLNA19, TP53BP1, SMG1, RANBP9, SMARCA4 and STAG3, were previously implicated in the DNA damage response [53]. 


\section{Double-Strand DNA Break Recognition and Repair}

After the introduction of DSB, it is detected rapidly. The DNA damage is quickly detected by poly [ADP-ribose] polymerase 1 (PARP1), which catalyzes the formation of poly (ADP-ribose) chain facilitated attachment of the MRN (MRE11, RAD50, NBS1) complex at the DNA damage site. It is also postulated that both PARP1 and MRN are double-stranded DNA break sensors, which recognize different types of damage $[18,19,54,55]$.

The activation of the DDR signal cascade requires an interaction between the MRN complex and ATM serine/threonine kinase. ATM kinase is the most common intermediate in a number of cellular responses to IR-induced damage $[18,56,57]$. While the MRN complex is attached to a DNA double-strand break site, the carboxy terminus of the NBS1 protein interacts with ATM and recruits it to the site of DNA damage where its activation takes place. ATM occurs in an inactive form as a homodimer, which is self-activated by phosphorylation after recruitment to the DNA damage site.

ATM undergoes autophosphorylation on Ser 1981, which leads to the breakdown of the inactive dimer into catalytically active monomers [58-60]. Moreover, Kozlov et al. confirmed that ATM also undergoes autophosphorylation on Ser367 and Ser1893, thus recruits ATM to broken DNA molecules [58].

The scope of the ATM-mediated in DDR is very wide. Active ATM kinase monomers phosphorylate over 700 protein substrates of this kinase. ATM functions focus on activating DNA repair proteins and cell cycle checkpoint-related factors [58,61,62].

Histone H2AX is rapidly phosphorylated at the C-terminal Ser residues (Ser136 and Ser139). The phosphorylation of H2AX on Ser 136 and 139, named $\gamma$-H2AX, leads to chromatin modification, which allows other DDR protein components to be recruited. However, upon the recognition of DNA lesions, the deregulation of DDR and other self-repair mechanisms may lead to cell radiosensitivity to radiation therapy. The overexpression of miR-24 and miR-138 targets the histone H2AX transcript at $3^{\prime}$-UTR, which leads to the downregulation of the H2AX histone coding gene and reduces the formation of foci of phosphorylated H2AX following DNA damage [63-66].

C-NHEJ predominates in the G1 phase, whereas it can occur in other cell cycle phases, when an intact sister chromatid is unavailable to guide the accurate HR repair mechanism [67]. Cohesive ends in the DSBs may be simply joined in the C-NHEJ pathway, but if the DNA contains blunt ends, it may result in the deletion or insertion of base pairs. Therefore, the DSBs generated by irradiation require a set of NHEJ factors which ensure rapid repair and maintenance of genome integrity. An alternative form of NHEJ which can be unmasked in the absence of functional C-NHEJ genes are described as alternative end-joining (alt-NHEJ or A-EJ) pathways [68,69].

A-EJ is also described as microhomology-mediated end joining (MMEJ) and is associated with deletions at the repair end junctions. This repair process requires end resection and microhomology sequences that are distant from the DSB. The A-EJ is suppressed by C-NHEJ and HR, although if these standard repair processes fail because a cell is deficient in C-NHEJ crucial proteins, the A-EJ is recruited to repair the damage $[69,70]$.

HR repair is restricted to the $S, G 2$ and $M$ phases to ensure the correct cell divisions. The activity of HR involves resection at the DSB and repair using a DNA homology template, leading to accurate repair, although occasionally it may also contribute to mutation, albeit to a much lesser extent [71,72].

The single strand annealing (SSA) is mainly active in yeast and mediates end joining between interspersed nucleotide repeats. The repair pathway is independent of the cell cycle and is not associated with the requirement that a sister chromatid be present. This is a homology-directed repair which removes DSBs by annealing a DNA segment close to the break with a neighboring homologue, leading to deletion of genetic information between the repeats [73,74].

Unrepaired DNA damage causes cancer cell death by apoptosis, necrosis or mitotic catastrophe. The mode of the cell death depends on the cell type, cell cycle phase, dose of irradiation and cancer environmental properties such as oxygen availability $[75,76]$. Some double-strand DNA breaks are very difficult to repair. They remain persistent and do not lead to cell death but bring it to a state of senescence $[55,77,78]$. The senescence-associated secretory phenotype (SASP) is responsible for the 
induction of inflammatory cytokines, extracellular matrix remodeling and the stimulation of angiogenesis to promote tumor growth and metastasis formation. Some factors, such as those secreted from stroma cells, can reverse the senescence of cancer cells, which is a common cause of cancer recurrence [78-80].

Cancer cells are highly heterogeneous. One population of these cells-cancer stem cells (CSCs), characterized by the ability of self-renewal and indicated as the main cause of cancer metastasis-are highly resistant to ionizing radiation $[81,82]$.

The incapability of DDR and DSBs repair pathways is commonly considered to be a cause of carcinogenesis by increasing the mutation rate, which-in consequence-leads to the development of heterogeneous lineages of cancer cells and resistance to chemo-radiotherapy [83-85]. On the other hand, targeting some of its components leads to the sensitization of cancer to IR. As indicated, the inhibition of important HR repair components, such as recombinase RAD51, provides promising results in terms of sensitizing cancer cells to radiotherapy [55,86-93].

Repair based on a homology template allows DNA damage to be repaired accurately and the risk of mutagenesis to be reduced. Although HR repair might not be completely error free, it is much less mutagenic than NHEJ [84,94-98]. The NHEJ deficiency is less often observed in context of tumorigenesis than HR $[99,100]$. Therefore, HR is a good candidate for use in cancer therapy based on the synthetic lethality strategy.

The synthetic lethality strategy is dedicated to cells with mutations, polymorphisms or epigenetic changes that cause a loss of function of one of the DNA repair proteins, as a highly redundant DNA repair system uses an alternative or complementary pathway to repair the damage. Through the additional artificial inactivation of the relevant genes of those pathways, DNA repair in pathological cells can be significantly impaired, thus leading to selective death. MicroRNAs are promising candidates for such inactivating agents $[101,102]$. A scheme of the potential microRNA participation in generating synthetic lethality is shown in Figure 3.

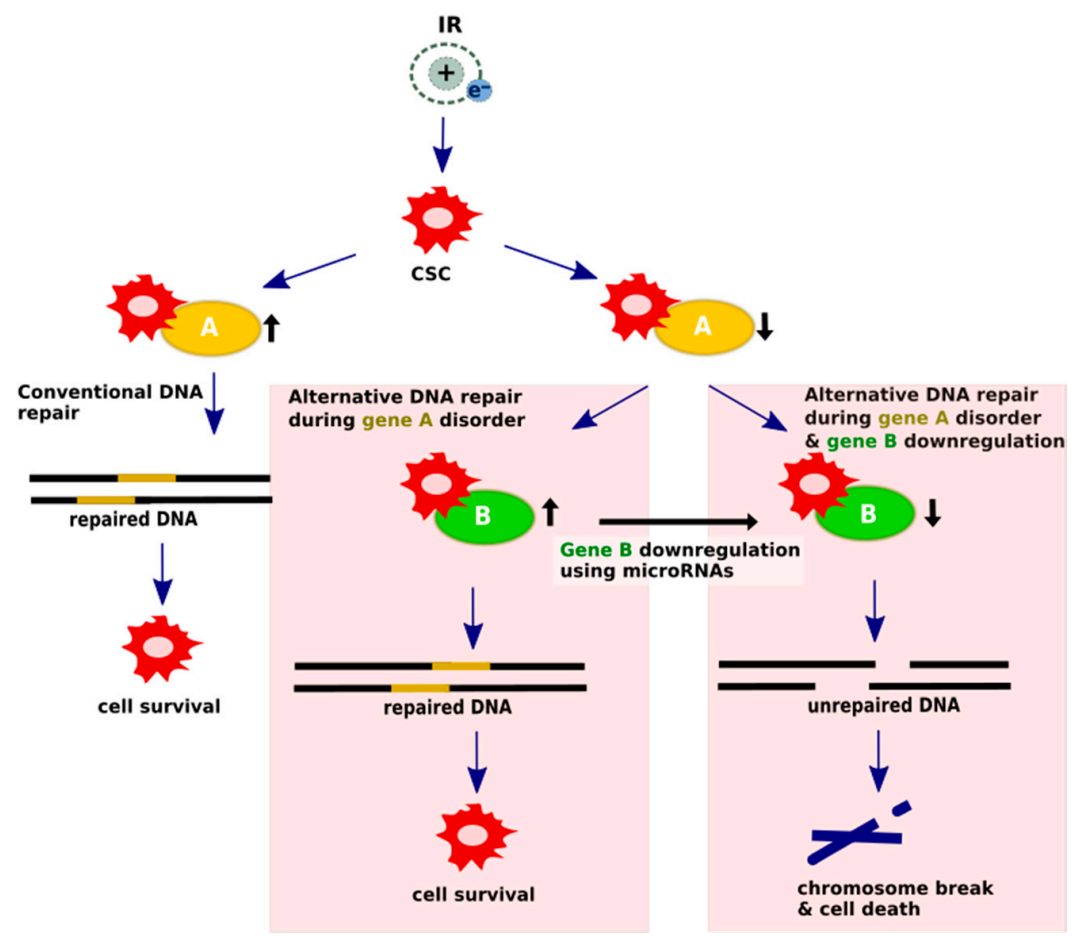

Figure 3. Synthetic lethality mechanism undergoes microRNA regulation. In conventional pathways, DSBs are repaired and cells are able to survive; however, cells with DNA-repair protein deficiencies rely heavily on alternative mechanisms to repair damaged DNA. The concept of alternative DNA repair pathways using microRNA modulation assumes that silencing a crucial gene factor provides chromosome discontinuity and cell death. Upregulated DNA damage repair genes are assigned as black arrows pointing up, while suppressed genes are presented as black arrows pointing down. 


\section{MicroRNA Regulation of DNA Double-Strand Break Recognition and Homologous Recombination Repair after IR Exposure}

MiRNAs that regulate several important DDR proteins are demonstrated on Figure 4 and Table 1; Table 2. Several miRNAs that sensitize cells to IR by targeting the 3'-UTR of ATM have been identified in cancer cells. Upregulated miRNAs include the following: miR-18a [103], miR-26a [104], miR-27a [105], miR-100 [106], miR-101 [107], miR-106a [108,109], miR-203 [110], miR-223 [111], and miR-421 [112], leading to the suppression of the ATM gene and formation of its protein product at nuclear foci. Furthermore, miR-421 is upregulated by the proto-oncogene protein, N-Myc, transcription factor that establishes some signaling cascades (miR-421/N-Myc/ATM) that causes cell radiosensitivity [112]. The key downstream target substrate, phosphorylated by ATM, is checkpoint protein 2 (Chk2), mediating the effects of ATM on DNA damage repair mechanisms and other cellular responses that consequently halt the cell cycle [113]. Chk2 subsequently phosphorylates p53 (a tumor suppressor protein), because its activation determines the fate of the cell. Moreover, p53 is also stimulated directly by ATM kinase [114]. The overexpression of miR-125b [115], miR-375 [116], miR-504 [117] and miR-630 [118], leading to the repression of the endogenous level of p53 protein, and the loss of the p53-coding gene function, predisposes the organism to tumor growth.

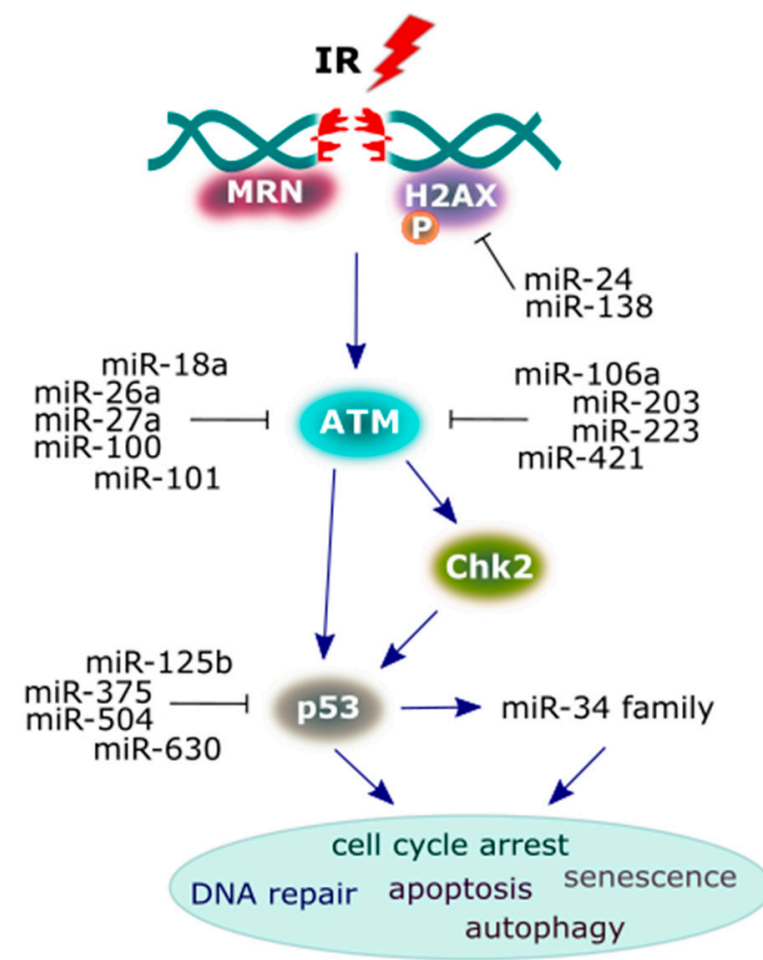

Figure 4. A scheme presenting the major proteins of the DNA damage response (DDR) signaling pathway and the miRNAs that interact with them. Following the induction of DNA double-strand breaks (DSBs) by irradiation, the reaction initiates protein components, such as sensors (MRN/H2AX), transducers (ATM/BRCA1/checkpoint protein 2 (Chk2)) and the effector protein (p53) in order to achieve a cellular response. Multiple miRNAs play a crucial role in the suppression of these DDR proteins in irradiated cancer cells, and some of these proteins may activate miRNAs, leading to a specific cellular response (see the main text for more details).

The tumor suppressor p53 mainly acts as a transcription factor. After IR exposure, p53 undergoes post-translational modification, leading to the induction and/or inhibition of many transcriptionally activate target genes $[119,120]$. The connection between p53 and miRNAs is also described. MiRNAs are considered to be intrinsic components of the p53 pathway. Among the current data, three miR-34 family members (miR-34a, miR-34b, and miR-34c) have been identified that are transcriptionally 
activated by the p53 protein. The miR-34 family is encoded at two distinct genomic loci-mir34a and mir34b/c — that contain identical seed sequences. In addition, in mammalian cells, the miR-34 family is often expressed by p53 in response to IR. Due to reductions in the level of miR-34 expression in a variety of tumor cases, as well as associated genomic deletions and promoter hypermethylation, it was confirmed that miR-34 can play a role as a radiosensitizing agent and potential therapeutic target in an anti-miR-34 approach [121,122].

Ionizing radiation induces RAD51 nuclear foci formation and the regulation of HR repair by miRNAs. A growing body of evidence clearly indicates that miRNAs are specifically regulated with regard to IR dose and DNA repair time in response to IR. Moreover, some miRNAs can promote the overexpression of certain HR factors in several cell lines or may lead to the downregulation of another HR protein in other cells [123,124].

The MRN complex is responsible for the initial recognition of DSBs that generate single-stranded DNA and G2/M checkpoint arrest for HR repair. During HR processes in eukaryotic cells, RAD51 participates in the majority of the repair (Figure 5) [125-127]. As a central player in the HR mechanism, RAD51 is overexpressed in tumor cells, because malignant cancer cells often bear p53 mutations in tandem with a low-level DNA damage sensitivity caused by chemo- and radiotherapy treatment [120,128-131].

Table 1. MicroRNAs that affect DNA damage response and homologous recombination repair downregulated after irradiation.

\begin{tabular}{|c|c|c|c|c|}
\hline miRNAs & Target Proteins & $\begin{array}{l}\text { Studied Material } \\
\text { and IR Dose }\end{array}$ & $\begin{array}{l}\text { Predicted Consequences } \\
\text { for Cells }\end{array}$ & References \\
\hline $\begin{array}{l}\operatorname{miR}-155 \\
\operatorname{miR}-375\end{array}$ & RAD51 p53 & $\begin{array}{c}\text { Thirty-two male FVB/NJ } \\
\text { mice, } 12 \text { weeks old/liver } \\
\text { tissue } \\
\text { Dose: } 28 \mathrm{mGy}\end{array}$ & - & {$[116,132,133]$} \\
\hline $\operatorname{miR}-34 a$ & c-Мyc & $\begin{array}{l}\text { Human colorectal cancer } \\
\text { cells HCT116 p53-/- } \\
\text { Doses: 2; 4; } 8 \text { Gy } \\
\text { Human non-small-cell }\end{array}$ & $\begin{array}{l}\text { MiR-34a is a critical } \\
\text { mediator of p53 function. }\end{array}$ & {$[134,135]$} \\
\hline & c-Myc & $\begin{array}{l}\text { lung carcinoma (NSCLC) } \\
\text { H460 } \\
\text { Doses: 1; 2; } 5 \text { Gy }\end{array}$ & Senescence-promoting effect. & \\
\hline $\begin{array}{c}\text { miR-24, } \\
\text { miR-103 \& miR-107, } \\
\text { miR-106a, } \\
\text { miR-155 }\end{array}$ & $\begin{array}{l}\text { H2AX, RAD51 } \\
\text { ATM RAD51 }\end{array}$ & $\begin{array}{c}\text { Human B lymphoblastic } \\
\text { cell line IM9 } \\
\text { Dose: } 1 \text { Gy }\end{array}$ & $\begin{array}{l}\text { MiR-34a may be involved in } \\
\text { the cell } \\
\text { cycle response and apoptosis } \\
\text { pathway in association with } \\
\text { p53. }\end{array}$ & $\begin{array}{c}{[26,64,108,133,} \\
136]\end{array}$ \\
\hline $\begin{array}{l}\text { miR-24, } \\
\text { miR-26b, } \\
\text { miR-125b, } \\
\text { miR-100 }\end{array}$ & $\begin{array}{l}\text { H2AX } \\
\text { ATM } \\
\text { p53 } \\
\text { ATM }\end{array}$ & $\begin{array}{l}\text { Normal human } \\
\text { fibroblasts AG01522 } \\
\text { Dose: } 10 \mathrm{~Gy}\end{array}$ & $\begin{array}{l}\text { Regulation of cellular } \\
\text { response following } \\
\text { irradiation. }\end{array}$ & $\begin{array}{c}{[64,104,106,137,} \\
138]\end{array}$ \\
\hline miR-203 & ATM & $\begin{array}{l}\text { Normal thyroid cells } \\
\text { Doses: } 1 ; 10 \mathrm{~Gy}\end{array}$ & $\begin{array}{l}\text { MiR-203 dysregulation is } \\
\text { associated with radiation } \\
\text { exposure and may be unique } \\
\text { for thyroid cells. }\end{array}$ & {$[139,140]$} \\
\hline miR-504 & p53 & $\begin{array}{c}\text { Human head and } \\
\text { neck epithelial } \\
\text { malignancy, } \\
\text { nasopharyngeal } \\
\text { carcinoma (NPC), } \\
\text { radio-resistant cell lines } \\
\text { CNE2-IR and HK1-IR } \\
\text { Doses: } 2 ; 4 ; 6 \mathrm{~Gy}\end{array}$ & $\begin{array}{l}\text { Induction of radioresistance } \\
\text { by down-regulating the } \\
\text { expression of NRF1 and } \\
\text { disturbing mitochondrial } \\
\text { respiratory function. }\end{array}$ & {$[117,141]$} \\
\hline
\end{tabular}

Several miRNAs have been described as important regulators of HR proteins, which change their expression level after irradiation treatment. HR repair activation is mediated through the ATM/Chk2/p53 signaling pathway and requires many protein factors (BRCA1, BRCA2, PALB2) and RAD51 paralogs (RAD51B, RAD51C, RAD51D, XRCC2, and XRCC3) for the proper post-translational modification of RAD51 and accurate repair after irradiation [142,143]. Manipulation of HR mechanism 
by using miRNAs regulation leads to a clear increase in radiosensitivity or IR-resistance promotion in many cancer cell lines [103,104,108,144,145]. For example, irradiation may promote RAD51 expression by downregulating miR-193b-3p in hepatocytes, whereas than the miRNAs (miR-1255b, miR-148b* and miR-193b*) are inhibited, the increased expression of BRCA1, BRCA2 and RAD51 is detected [123,146].

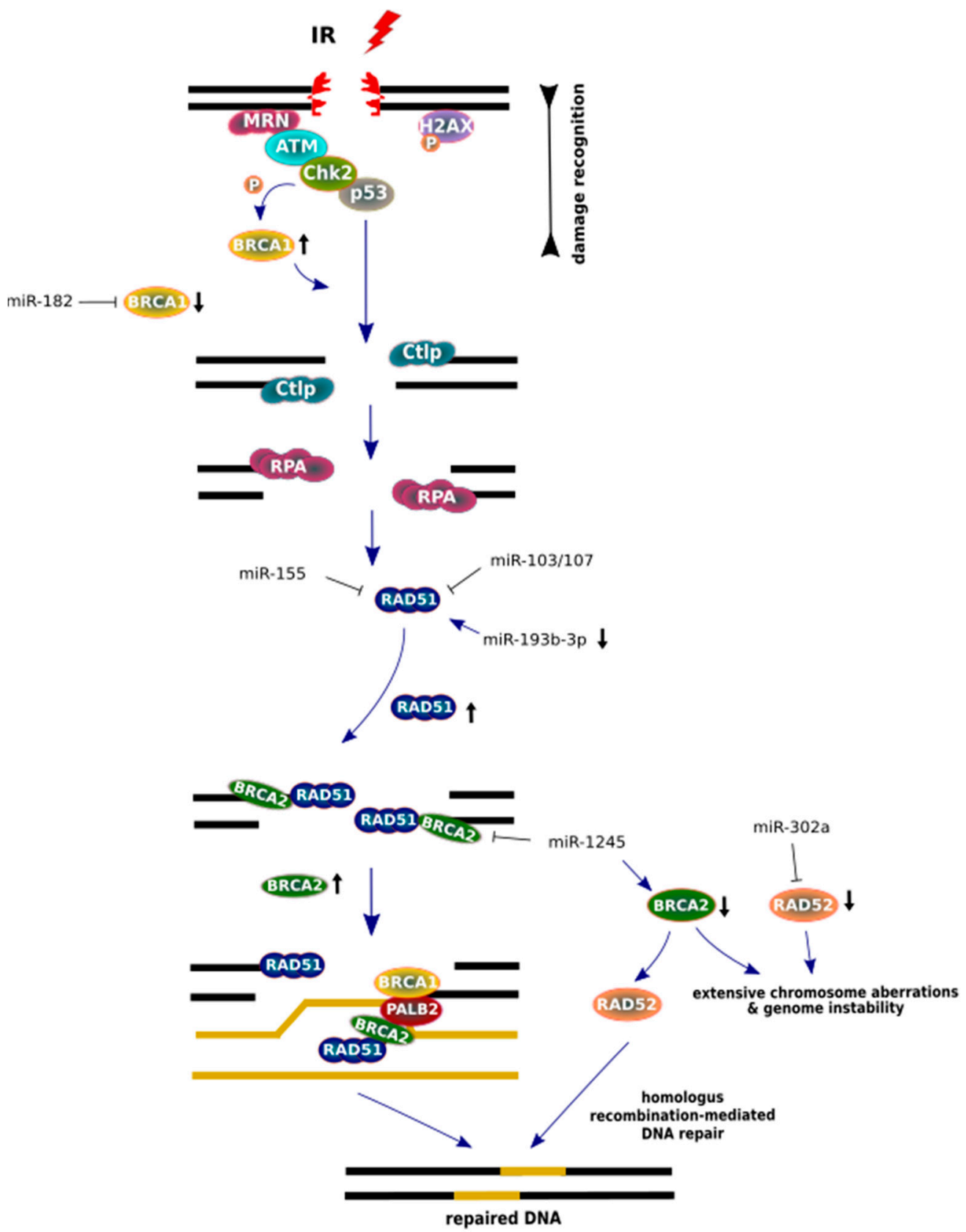

Figure 5. MiRNA regulation of homologous recombination (HR) repair factors after IR. After double strand break (DSB) recognition, BRCA1 (black arrow, pointing up) is phosphorylated by Chk2 kinase and an endonuclease CtIP is delivered for promotion end resection. While, at a later step of HR, BRCA1 recruits PALB2, which mediates promotion of BRCA2 to arrangement on the DNA template. Active BRCA2 (black arrow, pointing up) proteins displaces replication protein A (RPA) in order to load RAD51 onto the DNA. However, low BRCA2 protein levels cause increased levels of RAD52, which promote RAD51 for accurate homologous recombination (HR) repair in BRCA2-deficient cells. The lack of BRCA2 and RAD52 (black arrow, pointing down) causes the most severe genome defects. Major components of the HR pathway are arranged in a scheme based on the aspect of the miRNA regulation post-IR. 
Table 2. MicroRNAs that affect DNA damage response and homologous recombination repair upregulated after irradiation.

\begin{tabular}{|c|c|c|c|c|}
\hline miRNAs & Target Proteins & $\begin{array}{c}\text { Studied Material and IR } \\
\text { Dose }\end{array}$ & $\begin{array}{c}\text { Predicted } \\
\text { Consequences for Cells }\end{array}$ & References \\
\hline $\begin{array}{l}\text { miR-34a } \\
\text { miR-421 }\end{array}$ & $\begin{array}{l}\text { c-Myc } \\
\text { ATM }\end{array}$ & $\begin{array}{c}\text { Thirty-two male FVB/NJ mice, } \\
12 \text { weeks old / heart tissue. } \\
\text { Dose: } 28 \text { mGy }\end{array}$ & $\begin{array}{l}\text { The expression of } \\
\text { inflammation-related } \\
\text { miR-155 changed by low } \\
\text { dose irradiation. }\end{array}$ & {$[112,132,134]$} \\
\hline miR-375 & p53 & $\begin{array}{c}\text { Thirty-two FVB/NJ mice, } 12 \\
\text { weeks old testis tissue. } \\
\text { Dose: } 28 \mathrm{mGy}\end{array}$ & & \multirow{4}{*}[134,135,147]{} \\
\hline \multirow[t]{3}{*}{ miR-34a } & \multirow[t]{3}{*}{ c-Myc } & $\begin{array}{c}\text { Human colorectal cancer cells } \\
\text { HCT116 p53 +/+. } \\
\text { Dose: } 2 ; 4 ; 8 \text { Gy }\end{array}$ & $\begin{array}{l}\text { MiR-34a is a critical } \\
\text { mediator of p53 function. }\end{array}$ & \\
\hline & & $\begin{array}{l}\text { Human non-small cell lung } \\
\text { carcinoma (NSCLC) A549. } \\
\text { Dose: } 2 ; 5 ; 10 \text { Gy }\end{array}$ & $\begin{array}{l}\text { Senescence promoting } \\
\text { effect. }\end{array}$ & \\
\hline & & $\begin{array}{c}\text { Human breast cell line / } \\
\text { non-cancerous MCF-10A and } \\
\text { cancerous MCF 7. } \\
\text { Dose: } 5 \text { Gy for MCF-10A } \\
\text { additional doses: 3; 12; } 48 \\
\text { mGy }\end{array}$ & $\begin{array}{l}\text { Mir-34a is up-regulated } \\
\text { in p53 positive cancer } \\
\text { and normal cell. } \\
\text { MiR-34a might be } \\
\text { involved in breast cell } \\
\text { responses to low dose } \\
\text { radiation. }\end{array}$ & \\
\hline miR-18a & ATM & $\begin{array}{c}\text { Patients from radiosensitive } \\
\text { group /cervical cancer cells. } \\
\text { Dose: } 8 \mathrm{~Gy}\end{array}$ & $\begin{array}{l}\text { Attenuation of DNA } \\
\text { DSB repair and } \\
\text { re-sensitization of cancer } \\
\text { cells to radiotherapy by } \\
\text { promoting apoptosis. }\end{array}$ & {$[103,148]$} \\
\hline $\begin{array}{l}\mathrm{miR}-34 \mathrm{a} / \mathrm{b} \\
\mathrm{miR}-193 \mathrm{~b} \\
\mathrm{miR}-630\end{array}$ & $\begin{array}{c}\text { H2AX } \\
\text { BRCA1 BRCA2 } \\
\text { RAD51 } \\
\text { p53 }\end{array}$ & $\begin{array}{c}\text { Human B lymphoblastic cell } \\
\text { line IM9. } \\
\text { Dose: } 1 ; 10 \text { Gy }\end{array}$ & $\begin{array}{l}\text { MiR-34a may be } \\
\text { involved in the cell cycle } \\
\text { response and apoptosis } \\
\text { pathway associated with } \\
\text { p53. }\end{array}$ & $\begin{array}{c}{[123,134,136,149,} \\
150]\end{array}$ \\
\hline miR-106a & ATM & $\begin{array}{c}\text { Human prostate } \\
\text { adenocarcinoma cell line PC3 } \\
\text { Dose: } 6 \text { Gy }\end{array}$ & $\begin{array}{l}\text { Promotion of cell } \\
\text { survival and } \\
\text { proliferation ability after } \\
\text { irradiation. }\end{array}$ & [108] \\
\hline $\begin{array}{l}\text { miR-26b } \\
\text { miR-107 } \\
\text { miR-182 } \\
\text { miR-155 }\end{array}$ & $\begin{array}{l}\text { ATM } \\
\text { RAD51 } \\
\text { BRCA1 } \\
\text { RAD51 }\end{array}$ & $\begin{array}{c}\text { Human lymphoblast cell line } \\
\text { TK6. } \\
\text { Dose: } 2 \text { Gy }\end{array}$ & $\begin{array}{l}\text { Regulation the cellular } \\
\text { response to irradiation. }\end{array}$ & $\begin{array}{c}{[26,104,133,151} \\
152]\end{array}$ \\
\hline $\begin{array}{l}\text { miR-106a } \\
\text { miR-138 } \\
\text { miR-193b }\end{array}$ & $\begin{array}{l}\text { ATM } \\
\text { H2AX } \\
\text { BRACA1 } \\
\text { BRCA2 } \\
\text { RAD51 }\end{array}$ & $\begin{array}{c}\text { Human cell lines/head and } \\
\text { neck (SCC-4, SCC-25, CAL-27) } \\
\text { brain (LN229, T98G, U-87 MG). } \\
\text { Dose: } 2 \text { Gy }\end{array}$ & $\begin{array}{l}\text { MiRNAs induced } \\
\text { significant changes in } \\
\text { expression profiles. }\end{array}$ & {$[65,108,109,123]$} \\
\hline
\end{tabular}

It is important to note that IR induces RAD51 nuclear foci formation, which is cell cycle-dependent [153]. The regulation of HR proteins by specific miRNAs may promote genomic instability after IR exposure. For example, irradiation may promote RAD51 coding gene expression by downregulating miR-193b-3p in hepatocytes, whereas if miRNAs, including miR-103/107 and miR-155, are inhibited, then an increased expression of RAD51 is detected [26,133,146,154].

BRCA1, a tumor-suppressing protein, epigenetically represses miR-155 in lung cancer cell lines, and the inhibition of miR-155 may have anti-cancer potential in sensitizing hypoxic lung cancer $[144,155]$. On the other hand, it is considered that miRNAs such as miR-103 and miR-107 consistently reduce IR-induced RAD51 foci formation in endometrial and bone cancer cell lines [156]. As a result of radiation, the transcripts of genes coding BRCA1 are targeted by miR-182 overexpression, which leads to gene silencing [152]. BRCA1 interacts with numerous molecules and its deficiency is often related to breast cancer development. However, a clinical prognostic factor, BRCA2, is also co-localized with RAD51 and the RAD51/PALB2/BRCA1 complex during HR repair. In breast cancer cells, the 
upregulation of miR-1245 is noted after IR treatment. The inhibition of miR-1245 may enhance BRCA2 expression and RAD51 nuclear foci formation [157-161]. Feng et al. showed that RAD52 plays a role as an alternative factor that is essential for the survival of BRCA2-deficient cells, while RAD52 deletion may reduce cancer progression [162]. MiR-302 represses RAD52 transcripts in breast cancer cells, providing to radioresistance and allow cancer cells to survive [163].

\section{Conclusions}

Short non-coding RNAs, miRNAs, regulate many cellular factors, which participate in DDR and HR repair mechanisms after irradiation.

Following irradiation, miRNAs are involved in regulating HR repair in several ways. HR transcripts can be mediated by downregulation or upregulation. On account of IR exposure, some HR proteins may promote the expression of miRNAs, which regulate another protein related to the HR mechanism.

MiRNA regulators may play a role as prognostic factors in cancers.

The sensitization of cancer cells to ionizing radiation by the deregulation of DNA damage response proteins can be crucial for the elevation of effective cancer therapy.

Author Contributions: Conceptualization, R.K. and M.S.; writing-original draft preparation, M.S.; writing-review and editing, R.K.; visualization, M.S.; supervision, R.K. All authors have read and agreed to the published version of the manuscript.

Funding: This research received no external funding.

Conflicts of Interest: The authors declare no conflict of interest.

\section{References}

1. Mill, A.J.; Wells, J.; Hall, S.C.; Butler, A. Micronucleus induction in human lymphocytes: Comparative effects of $X$ rays, alpha particles, beta particles and neutrons and implications for biological dosimetry. Radiat. Res. 1996, 145, 575-585. [CrossRef]

2. Paganetti, H.; Gerweck, L.E.; Goitein, M. The general relation between tissue response to x-radiation (alpha/beta-values) and the relative biological effectiveness (RBE) of protons: Prediction by the Katz track-structure model. Int. J. Radiat. Biol. 2000, 76, 985-998. [CrossRef] [PubMed]

3. IARC. Ionizing radiation, part 1: X- and gamma-radiation, and neutrons. Overall introduction. IARC Monogr. Eval. Carcinog. Risks Hum. 2000, 75 Pt 1, 35-115.

4. Santivasi, W.L.; Xia, F. Ionizing Radiation-Induced DNA Damage, Response, and Repair. Antioxid. Redox Signal. 2014, 21, 251-259. [CrossRef] [PubMed]

5. Vignard, J.; Mirey, G.; Salles, B. Ionizing-radiation induced DNA double-strand breaks: A direct and indirect lighting up. Radiother. Oncol. 2013, 108, 362-369. [CrossRef] [PubMed]

6. Ahmad, S.S.; Duke, S.; Jena, R.; Williams, M.V.; Burnet, N.G. Advances in radiotherapy. BMJ 2012, 345 , e7765. [CrossRef] [PubMed]

7. Téoule, R. Radiation-induced DNA Damage and Its Repair. Int. J. Radiat. Biol. Relat. Stud. Phys. Chem. Med. 1987, 51, 573-589. [CrossRef] [PubMed]

8. Jackson, S.P.; Bartek, J. The DNA-damage response in human biology and disease. Nature 2009, 461, 1071-1078. [CrossRef] [PubMed]

9. Abshire, D.; Lang, M.K. The Evolution of Radiation Therapy in Treating Cancer. Semin. Oncol. Nurs. 2018, 34, 151-157. [CrossRef]

10. Martin, O.A.; Martin, R.F. Cancer Radiotherapy: Understanding the Price of Tumor Eradication. Front. Cell Dev. Biol. 2020, 8. [CrossRef]

11. Vilalta, M.; Rafat, M.; Graves, E.E. Effects of radiation on metastasis and tumor cell migration. Cell. Mol. Life Sci. 2016, 73, 2999-3007. [CrossRef] [PubMed]

12. Helleday, T.; Lo, J.; van Gent, D.C.; Engelward, B.P. DNA double-strand break repair: From mechanistic understanding to cancer treatment. DNA Repair (Amst.) 2007, 6, 923-935. [CrossRef] [PubMed] 
13. Takata, M.; Sasaki, M.S.; Sonoda, E.; Morrison, C.; Hashimoto, M.; Utsumi, H.; Yamaguchi-Iwai, Y.; Shinohara, A.; Takeda, S. Homologous recombination and non-homologous end-joining pathways of DNA double-strand break repair have overlapping roles in the maintenance of chromosomal integrity in vertebrate cells. EMBO J. 1998, 17, 5497-5508. [CrossRef] [PubMed]

14. Hagen, U. Mechanisms of induction and repair of DNA double-strand breaks by ionizing radiation: Some contradictions. Radiat. Environ. Biophys. 1994, 33, 45-61. [CrossRef]

15. Torgovnick, A.; Schumacher, B. DNA repair mechanisms in cancer development and therapy. Front. Genet. 2015, 6, 157. [CrossRef]

16. Nowsheen, S.; Yang, E.S. The intersection between DNA damage response and cell death pathways. Exp. Oncol. 2012, 34, 243-254. [PubMed]

17. Breimer, L.H.; Lindahl, T. Thymine lesions produced by ionizing radiation in double-stranded DNA. Biochemistry 1985, 24, 4018-4022. [CrossRef] [PubMed]

18. Zhu, H.; Wei, M.; Xu, J.; Hua, J.; Liang, C.; Meng, Q.; Zhang, Y.; Liu, J.; Zhang, B.; Yu, X.; et al. PARP inhibitors in pancreatic cancer: Molecular mechanisms and clinical applications. Mol. Cancer 2020, 19. [CrossRef] [PubMed]

19. Wang, L.; Wang, Q.; Xu, Y.; Cui, M.; Han, L. Advances in the Treatment of Ovarian Cancer Using PARP Inhibitors and the Underlying Mechanism of Resistance. Curr. Drug Targets 2020, 21, 167-178. [CrossRef]

20. Wang, H.; Zhang, S.; Song, L.; Qu, M.; Zou, Z. Synergistic lethality between PARP-trapping and alantolactone-induced oxidative DNA damage in homologous recombination-proficient cancer cells. Oncogene 2020, 39, 2905-2920. [CrossRef]

21. Toma, M.; Sullivan-Reed, K.; Śliwiński, T.; Skorski, T. RAD52 as a Potential Target for Synthetic Lethality-Based Anticancer Therapies. Cancers 2019, 11, 1561. [CrossRef] [PubMed]

22. Somyajit, K.; Mishra, A.; Jameei, A.; Nagaraju, G. Enhanced non-homologous end joining contributes toward synthetic lethality of pathological RAD51C mutants with poly (ADP-ribose) polymerase. Carcinogenesis 2015, 36, 13-24. [CrossRef] [PubMed]

23. Stachelek, G.C.; Peterson-Roth, E.; Liu, Y.; Fernandez, R.J.; Pike, L.R.G.; Qian, J.M.; Abriola, L.; Hoyer, D.; Hungerford, W.; Merkel, J.; et al. YU238259 Is a Novel Inhibitor of Homology-Dependent DNA Repair That Exhibits Synthetic Lethality and Radiosensitization in Repair-Deficient Tumors. Mol. Cancer Res. 2015, 13, 1389-1397. [CrossRef] [PubMed]

24. Sizemore, S.T.; Mohammad, R.; Sizemore, G.M.; Nowsheen, S.; Yu, H.; Ostrowski, M.C.; Chakravarti, A.; Xia, F. Synthetic Lethality of PARP Inhibition and Ionizing Radiation is p53-dependent. Mol. Cancer Res. 2018, 16, 1092-1102. [CrossRef] [PubMed]

25. Czochor, J.R.; Glazer, P.M. microRNAs in cancer cell response to ionizing radiation. Antioxid. Redox Signal. 2014, 21, 293-312. [CrossRef] [PubMed]

26. Huang, J.-W.; Wang, Y.; Dhillon, K.K.; Calses, P.; Villegas, E.; Mitchell, P.S.; Tewari, M.; Kemp, C.J.; Taniguchi, T. Systematic screen identifies miRNAs that target RAD51 and RAD51D to enhance chemosensitivity. Mol. Cancer Res. 2013, 11, 1564-1573. [CrossRef] [PubMed]

27. Piotto, C.; Biscontin, A.; Millino, C.; Mognato, M. Functional validation of miRNAs targeting genes of DNA double-strand break repair to radiosensitize non-small lung cancer cells. Biochim. Biophys. Acta Gene Regul. Mech. 2018, 1861, 1102-1118. [CrossRef] [PubMed]

28. Griffiths-Jones, S. miRBase: The microRNA sequence database. Methods Mol. Biol. 2006, 342, $129-138$. [CrossRef] [PubMed]

29. Galatenko, V.V.; Galatenko, A.V.; Samatov, T.R.; Turchinovich, A.A.; Shkurnikov, M.Y.; Makarova, J.A.; Tonevitsky, A.G. Comprehensive network of miRNA-induced intergenic interactions and a biological role of its core in cancer. Sci. Rep. 2018, 8, 2418. [CrossRef] [PubMed]

30. Liu, Y.; Wang, L.; Chen, D.; Wu, X.; Huang, D.; Chen, L.; Li, L.; Deng, X.; Xu, Q. Genome-wide comparison of microRNAs and their targeted transcripts among leaf, flower and fruit of sweet orange. BMC Genomics 2014, 15, 695. [CrossRef] [PubMed]

31. Shepard, P.J.; Choi, E.-A.; Lu, J.; Flanagan, L.A.; Hertel, K.J.; Shi, Y. Complex and dynamic landscape of RNA polyadenylation revealed by PAS-Seq. RNA 2011, 17, 761-772. [CrossRef] [PubMed]

32. Mayr, C. Regulation by 3'-Untranslated Regions. Annu. Rev. Genet. 2017, 51, 171-194. [CrossRef] [PubMed]

33. Mayr, C. Evolution and Biological Roles of Alternative 3'UTRs. Trends Cell Biol. 2016, 26, 227-237. [CrossRef] [PubMed] 
34. Brennecke, J.; Stark, A.; Russell, R.B.; Cohen, S.M. Principles of microRNA-target recognition. PLoS Biol. 2005, 3, e85. [CrossRef] [PubMed]

35. Barreau, C.; Paillard, L.; Osborne, H.B. AU-rich elements and associated factors: Are there unifying principles? Nucleic Acids Res. 2005, 33, 7138-7150. [CrossRef] [PubMed]

36. Bartel, D.P. MicroRNAs: Target recognition and regulatory functions. Cell 2009, 136, 215-233. [CrossRef] [PubMed]

37. Chen, C.Y.; Shyu, A.B. AU-rich elements: Characterization and importance in mRNA degradation. Trends Biochem. Sci. 1995, 20, 465-470. [CrossRef]

38. Mayr, C.; Bartel, D.P. Widespread shortening of 3'UTRs by alternative cleavage and polyadenylation activates oncogenes in cancer cells. Cell 2009, 138, 673-684. [CrossRef]

39. Qiu, M.; Liu, Y.; Zhou, Z.; Jiang, Y.; Lin, Q.; Huo, R.; Liang, X.; Yu, X.; Zhou, X.; Yu, H. Association between Single-Nucleotide Polymorphism in MicroRNA Target Site of DDB2 and Risk of Hepatocellular Carcinoma in a Southern Chinese Population. Biomed. Res. Int. 2020, 2020, 8528747. [CrossRef]

40. Teo, M.T.W.; Landi, D.; Taylor, C.F.; Elliott, F.; Vaslin, L.; Cox, D.G.; Hall, J.; Landi, S.; Bishop, D.T.; Kiltie, A.E. The role of microRNA-binding site polymorphisms in DNA repair genes as risk factors for bladder cancer and breast cancer and their impact on radiotherapy outcomes. Carcinogenesis 2012, 33, 581-586. [CrossRef]

41. Zhu, L.; Sturgis, E.M.; Zhang, H.; Lu, Z.; Tao, Y.; Wei, Q.; Li, G. Genetic variants in microRNA-binding sites of DNA repair genes as predictors of recurrence in patients with squamous cell carcinoma of the oropharynx. Int. J. Cancer 2017, 141, 1355-1364. [CrossRef] [PubMed]

42. Naccarati, A.; Rosa, F.; Vymetalkova, V.; Barone, E.; Jiraskova, K.; Di Gaetano, C.; Novotny, J.; Levy, M.; Vodickova, L.; Gemignani, F.; et al. Double-strand break repair and colorectal cancer: Gene variants within 3' UTRs and microRNAs binding as modulators of cancer risk and clinical outcome. Oncotarget 2016, 7, 23156-23169. [CrossRef] [PubMed]

43. Wu, W.; Wu, L.; Zhu, M.; Wang, Z.; Wu, M.; Li, P.; Nie, Y.; Lin, X.; Hu, J.; Eskilsson, E.; et al. miRNA Mediated Noise Making of 3'UTR Mutations in Cancer. Genes (Basel) 2018, 9, 545. [CrossRef] [PubMed]

44. Douki, T.; Ravanat, J.-L.; Pouget, J.-P.; Testard, I.; Cadet, J. Minor contribution of direct ionization to DNA base damage inducedby heavy ions. Int. J. Radiat. Biol. 2006, 82, 119-127. [CrossRef]

45. Milligan, J.R.; Aguilera, J.A.; Nguyen, T.-T.D.; Paglinawan, R.A.; Ward, J.F. DNA strand-break yields after post-irradiation incubation with base excision repair endonucleases implicate hydroxyl radical pairs in double-strand break formation. Int. J. Radiat. Biol. 2000, 76, 1475-1483. [CrossRef] [PubMed]

46. Prise, K.M.; Pullar, C.H.L.; Michael, B.D. A study of endonuclease III-sensitive sites in irradiated DNA: Detection of $\alpha$-particle-induced oxidative damage. Carcinogenesis 1999, 20, 905-909. [CrossRef] [PubMed]

47. Dizdaroglu, M.; Jaruga, P. Mechanisms of free radical-induced damage to DNA. Free Radic. Res. 2012, 46, 382-419. [CrossRef] [PubMed]

48. Cadet, J.; Wagner, J.R. DNA Base Damage by Reactive Oxygen Species, Oxidizing Agents, and UV Radiation. Cold Spring Harb. Perspect. Biol. 2013, 5, a012559. [CrossRef] [PubMed]

49. Borrego-Soto, G.; Ortiz-López, R.; Rojas-Martínez, A. Ionizing radiation-induced DNA injury and damage detection in patients with breast cancer. Genet. Mol. Biol. 2015, 38, 420-432. [CrossRef] [PubMed]

50. Bishop, E.P.; Rohs, R.; Parker, S.C.J.; West, S.M.; Liu, P.; Mann, R.S.; Honig, B.; Tullius, T.D. A map of minor groove shape and electrostatic potential from hydroxyl radical cleavage patterns of DNA. ACS Chem. Biol. 2011, 6, 1314-1320. [CrossRef] [PubMed]

51. Hardie, M.E.; Gautam, S.D.; Murray, V. The genome-wide sequence preference of ionising radiation-induced cleavage in human DNA. Mol. Biol. Rep. 2019, 46, 3731-3745. [CrossRef]

52. Gautam, S.D.; Hardie, M.E.; Murray, V. The Sequence Preference of Gamma-Radiation-Induced Damage in End-Labeled DNA after Heat Treatment. Radiat. Res. 2018, 189, 238-250. [CrossRef] [PubMed]

53. Yard, B.D.; Adams, D.J.; Chie, E.K.; Tamayo, P.; Battaglia, J.S.; Gopal, P.; Rogacki, K.; Pearson, B.E.; Phillips, J.; Raymond, D.P.; et al. A genetic basis for the variation in the vulnerability of cancer to DNA damage. Nat. Commun. 2016, 7. [CrossRef] [PubMed]

54. Haince, J.-F.; McDonald, D.; Rodrigue, A.; Déry, U.; Masson, J.-Y.; Hendzel, M.J.; Poirier, G.G. PARP1-dependent kinetics of recruitment of MRE11 and NBS1 proteins to multiple DNA damage sites. J. Biol. Chem. 2008, 283, 1197-1208. [CrossRef] [PubMed] 
55. Alotaibi, M.; Sharma, K.; Saleh, T.; Povirk, L.F.; Hendrickson, E.A.; Gewirtz, D.A. Radiosensitization by PARP Inhibition in DNA Repair Proficient and Deficient Tumor Cells: Proliferative Recovery in Senescent Cells. Radiat. Res. 2016, 185, 229-245. [CrossRef] [PubMed]

56. Lamarche, B.J.; Orazio, N.I.; Weitzman, M.D. The MRN complex in double-strand break repair and telomere maintenance. FEBS Lett. 2010, 584, 3682-3695. [CrossRef] [PubMed]

57. Pandita, T.K.; Lieberman, H.B.; Lim, D.S.; Dhar, S.; Zheng, W.; Taya, Y.; Kastan, M.B. Ionizing radiation activates the ATM kinase throughout the cell cycle. Oncogene 2000, 19, 1386-1391. [CrossRef] [PubMed]

58. Kozlov, S.V.; Graham, M.E.; Jakob, B.; Tobias, F.; Kijas, A.W.; Tanuji, M.; Chen, P.; Robinson, P.J.; Taucher-Scholz, G.; Suzuki, K.; et al. Autophosphorylation and ATM activation: Additional sites add to the complexity. J. Biol. Chem. 2011, 286, 9107-9119. [CrossRef] [PubMed]

59. Zhou, H.; Kawamura, K.; Yanagihara, H.; Kobayashi, J.; Zhang-Akiyama, Q.-M. NBS1 is regulated by two kind of mechanisms: ATM-dependent complex formation with MRE11 and RAD50, and cell cycle-dependent degradation of protein. J. Radiat. Res. 2017, 58, 487-494. [CrossRef] [PubMed]

60. So, S.; Davis, A.J.; Chen, D.J. Autophosphorylation at serine 1981 stabilizes ATM at DNA damage sites. J. Cell Biol. 2009, 187, 977-990. [CrossRef] [PubMed]

61. Matsuoka, S.; Ballif, B.A.; Smogorzewska, A.; McDonald, E.R.; Hurov, K.E.; Luo, J.; Bakalarski, C.E.; Zhao, Z.; Solimini, N.; Lerenthal, Y.; et al. ATM and ATR substrate analysis reveals extensive protein networks responsive to DNA damage. Science 2007, 316, 1160-1166. [CrossRef] [PubMed]

62. Lau, W.C.Y.; Li, Y.; Liu, Z.; Gao, Y.; Zhang, Q.; Huen, M.S.Y. Structure of the human dimeric ATM kinase. Cell Cycle 2016, 15, 1117-1124. [CrossRef] [PubMed]

63. Sharma, A.; Singh, K.; Almasan, A. Histone H2AX phosphorylation: A marker for DNA damage. Methods Mol. Biol. 2012, 920, 613-626. [CrossRef] [PubMed]

64. Lal, A.; Pan, Y.; Navarro, F.; Dykxhoorn, D.M.; Moreau, L.; Meire, E.; Bentwich, Z.; Lieberman, J.; Chowdhury, D. miR-24-mediated downregulation of H2AX suppresses DNA repair in terminally differentiated blood cells. Nat. Struct. Mol. Biol. 2009, 16, 492-498. [CrossRef] [PubMed]

65. Wang, Y.; Huang, J.-W.; Li, M.; Cavenee, W.K.; Mitchell, P.S.; Zhou, X.; Tewari, M.; Furnari, F.B.; Taniguchi, T. MicroRNA-138 modulates DNA damage response by repressing histone H2AX expression. Mol. Cancer Res. 2011, 9, 1100-1111. [CrossRef] [PubMed]

66. Yang, H.; Luo, J.; Liu, Z.; Zhou, R.; Luo, H. MicroRNA-138 Regulates DNA Damage Response in Small Cell Lung Cancer Cells by Directly Targeting H2AX. Cancer Invest. 2015, 33, 126-136. [CrossRef] [PubMed]

67. Shibata, A.; Jeggo, P.A. Canonical DNA non-homologous end-joining; capacity versus fidelity. Br. J. Radiol. 2020, 20190966. [CrossRef] [PubMed]

68. Chaudhuri, J.; Basu, U.; Zarrin, A.; Yan, C.; Franco, S.; Perlot, T.; Vuong, B.; Wang, J.; Phan, R.T.; Datta, A.; et al. Evolution of the immunoglobulin heavy chain class switch recombination mechanism. Adv. Immunol. 2007, 94, 157-214. [CrossRef]

69. Kang, Y.-J.; Yan, C.T. Regulation of DNA repair in the absence of classical non-homologous end joining. DNA Repair (Amst.) 2018, 68, 34-40. [CrossRef]

70. Sallmyr, A.; Tomkinson, A.E. Repair of DNA double-strand breaks by mammalian alternative end-joining pathways. J. Biol. Chem. 2018, 293, 10536-10546. [CrossRef]

71. Jasin, M.; Rothstein, R. Repair of strand breaks by homologous recombination. Cold Spring Harb. Perspect. Biol. 2013, 5, a012740. [CrossRef] [PubMed]

72. Saleh-Gohari, N.; Helleday, T. Conservative homologous recombination preferentially repairs DNA double-strand breaks in the S phase of the cell cycle in human cells. Nucleic Acids Res. 2004, 32, 3683-3688. [CrossRef] [PubMed]

73. Johnson, R.D.; Jasin, M. Sister chromatid gene conversion is a prominent double-strand break repair pathway in mammalian cells. EMBO J. 2000, 19, 3398-3407. [CrossRef] [PubMed]

74. Liang, F.; Han, M.; Romanienko, P.J.; Jasin, M. Homology-directed repair is a major double-strand break repair pathway in mammalian cells. Proc. Natl. Acad. Sci. USA 1998, 95, 5172-5177. [CrossRef] [PubMed]

75. Maier, P.; Hartmann, L.; Wenz, F.; Herskind, C. Cellular Pathways in Response to Ionizing Radiation and Their Targetability for Tumor Radiosensitization. Int. J. Mol. Sci. 2016, 17, 102. [CrossRef] [PubMed]

76. Schulz, S.; Doller, A.; Pendini, N.R.; Wilce, J.A.; Pfeilschifter, J.; Eberhardt, W. Domain-specific phosphomimetic mutation allows dissection of different protein kinase $\mathrm{C}$ (PKC) isotype-triggered activities of the RNA binding protein HuR. Cell. Signal. 2013, 25, 2485-2495. [CrossRef] [PubMed] 
77. Chen, Z.; Cao, K.; Xia, Y.; Li, Y.; Hou, Y.; Wang, L.; Li, L.; Chang, L.; Li, W. Cellular senescence in ionizing radiation (Review). Oncol. Rep. 2019, 42, 883-894. [CrossRef]

78. Gonzalez, L.C.; Ghadaouia, S.; Martinez, A.; Rodier, F. Premature aging/senescence in cancer cells facing therapy: Good or bad? Biogerontology 2016, 17, 71-87. [CrossRef]

79. Chakradeo, S.; Elmore, L.W.; Gewirtz, D.A. Is Senescence Reversible? Curr. Drug Targets 2016, 17, 460-466. [CrossRef]

80. Saleh, T.; Bloukh, S.; Carpenter, V.J.; Alwohoush, E.; Bakeer, J.; Darwish, S.; Azab, B.; Gewirtz, D.A. Therapy-Induced Senescence: An “Old" Friend Becomes the Enemy. Cancers (Basel) 2020, 12, 822. [CrossRef]

81. Najafi, M.; Farhood, B.; Mortezaee, K. Cancer stem cells (CSCs) in cancer progression and therapy. J. Cell. Physiol. 2019, 234, 8381-8395. [CrossRef] [PubMed]

82. Rich, J.N. Cancer stem cells: Understanding tumor hierarchy and heterogeneity. Medicine (Baltimore) 2016, 95, S2-S7. [CrossRef] [PubMed]

83. McCormick, A.; Donoghue, P.; Dixon, M.; O’Sullivan, R.; O’Donnell, R.L.; Murray, J.; Kaufmann, A.; Curtin, N.J.; Edmondson, R.J. Ovarian Cancers Harbor Defects in Nonhomologous End Joining Resulting in Resistance to Rucaparib. Clin. Cancer Res. 2017, 23, 2050-2060. [CrossRef] [PubMed]

84. Sishc, B.J.; Davis, A.J. The Role of the Core Non-Homologous End Joining Factors in Carcinogenesis and Cancer. Cancers (Basel) 2017, 9, 81. [CrossRef]

85. Wallace, M.D.; Southard, T.L.; Schimenti, K.J.; Schimenti, J.C. Role of DNA damage response pathways in preventing carcinogenesis caused by intrinsic replication stress. Oncogene 2014, 33, 3688-3695. [CrossRef] [PubMed]

86. Sak, A.; Stueben, G.; Groneberg, M.; Böcker, W.; Stuschke, M. Targeting of Rad51-dependent homologous recombination: Implications for the radiation sensitivity of human lung cancer cell lines. Br. J. Cancer 2005, 92, 1089-1097. [CrossRef]

87. Squatrito, M.; Brennan, C.W.; Helmy, K.; Huse, J.T.; Petrini, J.H.; Holland, E.C. Loss of ATM/Chk2/p53 pathway components accelerates tumor development and contributes to radiation resistance in gliomas. Cancer Cell 2010, 18, 619-629. [CrossRef]

88. Chen, W.S.; Xu, P.Z.; Gottlob, K.; Chen, M.L.; Sokol, K.; Shiyanova, T.; Roninson, I.; Weng, W.; Suzuki, R.; Tobe, K.; et al. Growth retardation and increased apoptosis in mice with homozygous disruption of the Akt1 gene. Genes Dev. 2001, 15, 2203-2208. [CrossRef] [PubMed]

89. Chang, L.; Graham, P.H.; Hao, J.; Ni, J.; Bucci, J.; Cozzi, P.J.; Kearsley, J.H.; Li, Y. Acquisition of epithelial-mesenchymal transition and cancer stem cell phenotypes is associated with activation of the PI3K/Akt/mTOR pathway in prostate cancer radioresistance. Cell Death Dis. 2013, 4, e875. [CrossRef] [PubMed]

90. Gilbert, M.; Knox, S. Influence of Bcl-2 overexpression on $\mathrm{Na}+\mathrm{K}(+)$-ATPase pump activity: Correlation with radiation-induced programmed cell death. J. Cell. Physiol. 1997, 171, 299-304. [CrossRef]

91. Wang, J.-Q.; Chen, J.-H.; Chen, Y.-C.; Chen, M.-Y.; Hsieh, C.-Y.; Teng, S.-C.; Wu, K.-J. Interaction between NBS1 and the mTOR/Rictor/SIN1 complex through specific domains. PLoS ONE 2013, 8, e65586. [CrossRef] [PubMed]

92. Konings, K.; Belmans, N.; Vermeesen, R.; Baselet, B.; Lamers, G.; Janssen, A.; Isebaert, S.; Baatout, S.; Haustermans, K.; Moreels, M. Targeting the Hedgehog pathway in combination with X-ray or carbon ion radiation decreases migration of MCF-7 breast cancer cells. Int. J. Oncol. 2019. [CrossRef] [PubMed]

93. Zhang, F.; Ma, J.; Wu, J.; Ye, L.; Cai, H.; Xia, B.; Yu, X. PALB2 links BRCA1 and BRCA2 in the DNA-damage response. Curr. Biol. 2009, 19, 524-529. [CrossRef] [PubMed]

94. Tanori, M.; Pasquali, E.; Leonardi, S.; Giardullo, P.; Di Majo, V.; Taccioli, G.; Essers, J.; Kanaar, R.; Mullenders, L.H.; Atkinson, M.J.; et al. Opposite modifying effects of HR and NHEJ deficiency on cancer risk in Ptc1 heterozygous mouse cerebellum. Oncogene 2011, 30, 4740-4749. [CrossRef] [PubMed]

95. Rodgers, K.; McVey, M. Error-Prone Repair of DNA Double-Strand Breaks. J. Cell. Physiol. 2016, $231,15-24$. [CrossRef] [PubMed]

96. Deem, A.; Keszthelyi, A.; Blackgrove, T.; Vayl, A.; Coffey, B.; Mathur, R.; Chabes, A.; Malkova, A. Break-induced replication is highly inaccurate. PLoS Biol. 2011, 9, e1000594. [CrossRef]

97. Hicks, W.M.; Kim, M.; Haber, J.E. Increased mutagenesis and unique mutation signature associated with mitotic gene conversion. Science 2010, 329, 82-85. [CrossRef] 
98. Sugino, A.; Nitiss, J.; Resnick, M.A. ATP-independent DNA strand transfer catalyzed by protein(s) from meiotic cells of the yeast Saccharomyces cerevisiae. Proc. Natl. Acad. Sci. USA 1988, 85, 3683-3687. [CrossRef]

99. Thompson, L.H.; Schild, D. Recombinational DNA repair and human disease. Mutat. Res. 2002, 509, 49-78. [CrossRef]

100. Shen, Z.; Nickoloff, J.A. Mammalian Homologous Recombination Repair and Cancer Intervention. In DNA Repair, Genetic Instability, and Cancer; WORLD SCIENTIFIC: Singapore, 2007; pp. 119-156, ISBN 978-981-270-014-8.

101. Zhou, Y.; Dang, J.; Chang, K.-Y.; Yau, E.; Aza-Blanc, P.; Moscat, J.; Rana, T.M. miR-1298 Inhibits Mutant KRAS-Driven Tumor Growth by Repressing FAK and LAMB3. Cancer Res. 2016, 76, 5777-5787. [CrossRef]

102. Li, Y.; Zhu, Y.; Prochownik, E.V. MicroRNA-based screens for synthetic lethal interactions with c-Myc. RNA Dis. 2016, 3. [CrossRef]

103. Liu, S.; Pan, X.; Yang, Q.; Wen, L.; Jiang, Y.; Zhao, Y.; Li, G. MicroRNA-18a enhances the radiosensitivity of cervical cancer cells by promoting radiation-induced apoptosis. Oncol. Rep. 2015, 33, 2853-2862. [CrossRef] [PubMed]

104. Guo, P.; Lan, J.; Ge, J.; Nie, Q.; Guo, L.; Qiu, Y.; Mao, Q. MiR-26a enhances the radiosensitivity of glioblastoma multiforme cells through targeting of ataxia-telangiectasia mutated. Exp. Cell Res. 2014, 320, 200-208. [CrossRef] [PubMed]

105. Di Francesco, A.; De Pittà, C.; Moret, F.; Barbieri, V.; Celotti, L.; Mognato, M. The DNA-damage response to $\gamma$-radiation is affected by miR-27a in A549 cells. Int. J. Mol. Sci. 2013, 14, 17881-17896. [CrossRef] [PubMed]

106. Ng, W.L.; Yan, D.; Zhang, X.; Mo, Y.-Y.; Wang, Y. Over-expression of miR-100 is responsible for the low-expression of ATM in the human glioma cell line: M059J. DNA Repair (Amst.) 2010, 9, 1170-1175. [CrossRef] [PubMed]

107. Yan, D.; Ng, W.L.; Zhang, X.; Wang, P.; Zhang, Z.; Mo, Y.-Y.; Mao, H.; Hao, C.; Olson, J.J.; Curran, W.J.; et al. Targeting DNA-PKcs and ATM with miR-101 sensitizes tumors to radiation. PLoS ONE 2010, 5, e11397. [CrossRef] [PubMed]

108. Hoey, C.; Ray, J.; Jeon, J.; Huang, X.; Taeb, S.; Ylanko, J.; Andrews, D.W.; Boutros, P.C.; Liu, S.K. miRNA-106a and prostate cancer radioresistance: A novel role for LITAF in ATM regulation. Mol. Oncol. 2018, 12, 1324-1341. [CrossRef]

109. Niemoeller, O.M.; Niyazi, M.; Corradini, S.; Zehentmayr, F.; Li, M.; Lauber, K.; Belka, C. MicroRNA expression profiles in human cancer cells after ionizing radiation. Radiat. Oncol. 2011, 6, 29. [CrossRef]

110. Jiang, Y.; Jin, S.; Tan, S.; Shen, Q.; Xue, Y. MiR-203 acts as a radiosensitizer of gastric cancer cells by directly targeting ZEB1. Onco Targets Ther. 2019, 12, 6093-6104. [CrossRef]

111. Zhuang, G.; Meng, C.; Guo, X.; Cheruku, P.S.; Shi, L.; Xu, H.; Li, H.; Wang, G.; Evans, A.R.; Safe, S.; et al. A novel regulator of macrophage activation: miR-223 in obesity-associated adipose tissue inflammation. Circulation 2012, 125, 2892-2903. [CrossRef]

112. Hu, H.; Du, L.; Nagabayashi, G.; Seeger, R.C.; Gatti, R.A. ATM is down-regulated by N-Myc-regulated microRNA-421. Proc. Natl. Acad. Sci. USA 2010, 107, 1506-1511. [CrossRef]

113. Hirao, A.; Kong, Y.Y.; Matsuoka, S.; Wakeham, A.; Ruland, J.; Yoshida, H.; Liu, D.; Elledge, S.J.; Mak, T.W. DNA damage-induced activation of p53 by the checkpoint kinase Chk2. Science 2000, 287, 1824-1827. [CrossRef] [PubMed]

114. Cheng, Q.; Chen, J. Mechanism of p53 stabilization by ATM after DNA damage. Cell Cycle 2010, 9, 472-478. [CrossRef] [PubMed]

115. Le, M.T.N.; Teh, C.; Shyh-Chang, N.; Xie, H.; Zhou, B.; Korzh, V.; Lodish, H.F.; Lim, B. MicroRNA-125b is a novel negative regulator of p53. Genes Dev. 2009, 23, 862-876. [CrossRef] [PubMed]

116. Liu, Y.; Xing, R.; Zhang, X.; Dong, W.; Zhang, J.; Yan, Z.; Li, W.; Cui, J.; Lu, Y. miR-375 targets the p53 gene to regulate cellular response to ionizing radiation and etoposide in gastric cancer cells. DNA Repair (Amst.) 2013, 12, 741-750. [CrossRef] [PubMed]

117. Ford, N.A.; Dunlap, S.M.; Wheatley, K.E.; Hursting, S.D. Obesity, independent of p53 gene dosage, promotes mammary tumor progression and upregulates the p53 regulator microRNA-504. PLoS ONE 2013, 8, e68089. [CrossRef] [PubMed]

118. Lyu, Y.-Y.; Wang, F.-M.; Yang, X.-M.; Zhang, C.-C.; Gu, F.; Luo, T.-J.; Jiang, P.-C.; Zhang, R. MiR-630 acts as a tumor suppressor in cervical cancer and inhibits epithelial-mesenchymal transition in cervical cancer. Int. J. Clin. Exp. Pathol. 2017, 10, 972-983. 
119. Riley, T.; Sontag, E.; Chen, P.; Levine, A. Transcriptional control of human p53-regulated genes. Nat. Rev. Mol. Cell Biol. 2008, 9, 402-412. [CrossRef] [PubMed]

120. Fei, P.; El-Deiry, W.S. P53 and radiation responses. Oncogene 2003, 22, 5774-5783. [CrossRef]

121. Kato, M.; Paranjape, T.; Müller, R.U.; Ullrich, R.; Nallur, S.; Gillespie, E.; Keane, K.; Esquela-Kerscher, A.; Weidhaas, J.B.; Slack, F.J. The mir-34 microRNA is required for the DNA damage response in vivo in C. elegans and in vitro in human breast cancer cells. Oncogene 2009, 28, 2419-2424. [CrossRef]

122. Tanaka, N.; Toyooka, S.; Soh, J.; Kubo, T.; Yamamoto, H.; Maki, Y.; Muraoka, T.; Shien, K.; Furukawa, M.; Ueno, T.; et al. Frequent methylation and oncogenic role of microRNA-34b/c in small-cell lung cancer. Lung Cancer 2012, 76, 32-38. [CrossRef] [PubMed]

123. Choi, Y.E.; Pan, Y.; Park, E.; Konstantinopoulos, P.; De, S.; D’Andrea, A.; Chowdhury, D. MicroRNAs down-regulate homologous recombination in the G1 phase of cycling cells to maintain genomic stability. Elife 2014, 3, e02445. [CrossRef]

124. Peng, Y.; Croce, C.M. The role of MicroRNAs in human cancer. Signal Transduct. Target. Ther. 2016, 1, 15004. [CrossRef] [PubMed]

125. Liu, J.; Ehmsen, K.T.; Heyer, W.-D.; Morrical, S.W. Presynaptic filament dynamics in homologous recombination and DNA repair. Crit. Rev. Biochem. Mol. Biol. 2011, 46, 240-270. [CrossRef] [PubMed]

126. Gaines, W.A.; Godin, S.K.; Kabbinavar, F.F.; Rao, T.; VanDemark, A.P.; Sung, P.; Bernstein, K.A. Promotion of presynaptic filament assembly by the ensemble of S. cerevisiae Rad51 paralogues with Rad52. Nat. Commun. 2015, 6, 7834. [CrossRef] [PubMed]

127. Chen, L.; Nievera, C.J.; Lee, A.Y.-L.; Wu, X. Cell cycle-dependent complex formation of BRCA1.CtIP.MRN is important for DNA double-strand break repair. J. Biol. Chem. 2008, 283, 7713-7720. [CrossRef]

128. Perri, F.; Pisconti, S.; Della Vittoria Scarpati, G. P53 mutations and cancer: A tight linkage. Ann. Transl. Med. 2016, 4, 522. [CrossRef] [PubMed]

129. Hannay, J.A.F.; Liu, J.; Zhu, Q.-S.; Bolshakov, S.V.; Li, L.; Pisters, P.W.T.; Lazar, A.J.F.; Yu, D.; Pollock, R.E.; Lev, D. Rad51 overexpression contributes to chemoresistance in human soft tissue sarcoma cells: A role for p53/activator protein 2 transcriptional regulation. Mol. Cancer Ther. 2007, 6, 1650-1660. [CrossRef]

130. Olivier, M.; Hollstein, M.; Hainaut, P. TP53 mutations in human cancers: Origins, consequences, and clinical use. Cold Spring Harb. Perspect. Biol. 2010, 2, a001008. [CrossRef]

131. Martin, R.W.; Orelli, B.J.; Yamazoe, M.; Minn, A.J.; Takeda, S.; Bishop, D.K. RAD51 up-regulation bypasses BRCA1 function and is a common feature of BRCA1-deficient breast tumors. Cancer Res. 2007, 67, 9658-9665. [CrossRef]

132. Liang, X.; Zheng, S.; Cui, J.; Yu, D.; Yang, G.; Zhou, L.; Wang, B.; Cai, L.; Li, W. Alterations of MicroRNA Expression in the Liver, Heart, and Testis of Mice Upon Exposure to Repeated Low-Dose Radiation. Dose Response 2018, 16, 1559325818799561. [CrossRef] [PubMed]

133. Gasparini, P.; Lovat, F.; Fassan, M.; Casadei, L.; Cascione, L.; Jacob, N.K.; Carasi, S.; Palmieri, D.; Costinean, S.; Shapiro, C.L.; et al. Protective role of miR-155 in breast cancer through RAD51 targeting impairs homologous recombination after irradiation. Proc. Natl. Acad. Sci. USA 2014, 111, 4536-4541. [CrossRef] [PubMed]

134. He, X.; Yang, A.; McDonald, D.G.; Riemer, E.C.; Vanek, K.N.; Schulte, B.A.; Wang, G.Y. MiR-34a modulates ionizing radiation-induced senescence in lung cancer cells. Oncotarget 2017, 8, 69797-69807. [CrossRef] [PubMed]

135. Liu, C.; Zhou, C.; Gao, F.; Cai, S.; Zhang, C.; Zhao, L.; Zhao, F.; Cao, F.; Lin, J.; Yang, Y.; et al. MiR-34a in age and tissue related radio-sensitivity and serum miR-34a as a novel indicator of radiation injury. Int. J. Biol. Sci. 2011, 7, 221-233. [CrossRef] [PubMed]

136. Cha, H.J.; Shin, S.; Yoo, H.; Lee, E.-M.; Bae, S.; Yang, K.-H.; Lee, S.-J.; Park, I.-C.; Jin, Y.-W.; An, S. Identification of ionizing radiation-responsive microRNAs in the IM9 human B lymphoblastic cell line. Int. J. Oncol. 2009, 34. [CrossRef]

137. Wu, N.; Lin, X.; Zhao, X.; Zheng, L.; Xiao, L.; Liu, J.; Ge, L.; Cao, S. MiR-125b acts as an oncogene in glioblastoma cells and inhibits cell apoptosis through p53 and p38MAPK-independent pathways. Br. J. Cancer 2013, 109, 2853-2863. [CrossRef]

138. Simone, N.L.; Soule, B.P.; Ly, D.; Saleh, A.D.; Savage, J.E.; Degraff, W.; Cook, J.; Harris, C.C.; Gius, D.; Mitchell, J.B. Ionizing radiation-induced oxidative stress alters miRNA expression. PLoS ONE 2009, 4, e6377. [CrossRef] 
139. Zhou, Y.; Wan, G.; Spizzo, R.; Ivan, C.; Mathur, R.; Hu, X.; Ye, X.; Lu, J.; Fan, F.; Xia, L.; et al. miR-203 induces oxaliplatin resistance in colorectal cancer cells by negatively regulating ATM kinase. Mol. Oncol. 2014, 8, 83-92. [CrossRef]

140. Nikiforova, M.N.; Gandhi, M.; Gandi, M.; Kelly, L.; Nikiforov, Y.E. MicroRNA dysregulation in human thyroid cells following exposure to ionizing radiation. Thyroid 2011, 21, 261-266. [CrossRef]

141. Zhao, L.; Tang, M.; Hu, Z.; Yan, B.; Pi, W.; Li, Z.; Zhang, J.; Zhang, L.; Jiang, W.; Li, G.; et al. miR-504 mediated down-regulation of nuclear respiratory factor 1 leads to radio-resistance in nasopharyngeal carcinoma. Oncotarget 2015, 6, 15995-16018. [CrossRef] [PubMed]

142. Prakash, R.; Zhang, Y.; Feng, W.; Jasin, M. Homologous recombination and human health: The roles of BRCA1, BRCA2, and associated proteins. Cold Spring Harb. Perspect. Biol. 2015, 7, a016600. [CrossRef] [PubMed]

143. Sullivan, M.R.; Bernstein, K.A. RAD-ical New Insights into RAD51 Regulation. Genes (Basel) 2018, 9, 629. [CrossRef]

144. Babar, I.A.; Czochor, J.; Steinmetz, A.; Weidhaas, J.B.; Glazer, P.M.; Slack, F.J. Inhibition of hypoxia-induced miR-155 radiosensitizes hypoxic lung cancer cells. Cancer Biol. Ther. 2011, 12, 908-914. [CrossRef] [PubMed]

145. Moskwa, P.; Zinn, P.O.; Choi, Y.E.; Shukla, S.A.; Fendler, W.; Chen, C.C.; Lu, J.; Golub, T.R.; Hjelmeland, A.; Chowdhury, D. A functional screen identifies miRs that induce radioresistance in glioblastomas. Mol. Cancer Res. 2014, 12, 1767-1778. [CrossRef] [PubMed]

146. Lee, E.-S.; Won, Y.J.; Kim, B.-C.; Park, D.; Bae, J.-H.; Park, S.-J.; Noh, S.J.; Kang, Y.-R.; Choi, S.H.; Yoon, J.-H.; et al. Low-dose irradiation promotes Rad51 expression by down-regulating miR-193b-3p in hepatocytes. Sci. Rep. 2016, 6, 25723. [CrossRef] [PubMed]

147. Stankevicins, L.; Almeida da Silva, A.P.; Ventura Dos Passos, F.; Dos Santos Ferreira, E.; Menks Ribeiro, M.C.; G David, M.; J Pires, E.; Ferreira-Machado, S.C.; Vassetzky, Y.; de Almeida, C.E.; et al. MiR-34a is up-regulated in response to low dose, low energy X-ray induced DNA damage in breast cells. Radiat. Oncol. 2013, 8, 231. [CrossRef]

148. Guo, X.; Yang, C.; Qian, X.; Lei, T.; Li, Y.; Shen, H.; Fu, L.; Xu, B. Estrogen receptor $\alpha$ regulates ATM Expression through miRNAs in breast cancer. Clin. Cancer Res. 2013, 19, 4994-5002. [CrossRef] [PubMed]

149. Zhang, L.; Wang, C.; Xue, Z.-X. Inhibition of miR-630 enhances the cell resistance to radiation by directly targeting CDC14A in human glioma. Am. J. Transl. Res. 2017, 9, 1255-1265. [PubMed]

150. Li, Y.-J.; Du, L.; Aldana-Masangkay, G.; Wang, X.; Urak, R.; Forman, S.J.; Rosen, S.T.; Chen, Y. Regulation of miR-34b/c-targeted gene expression program by SUMOylation. Nucleic Acids Res. 2018, 46, 7108-7123. [CrossRef] [PubMed]

151. Chaudhry, M.A.; Omaruddin, R.A.; Brumbaugh, C.D.; Tariq, M.A.; Pourmand, N. Identification of radiation-induced microRNA transcriptome by next-generation massively parallel sequencing. J. Radiat. Res. 2013, 54, 808-822. [CrossRef]

152. Moskwa, P.; Buffa, F.M.; Pan, Y.; Panchakshari, R.; Gottipati, P.; Muschel, R.J.; Beech, J.; Kulshrestha, R.; Abdelmohsen, K.; Weinstock, D.M.; et al. miR-182-mediated downregulation of BRCA1 impacts DNA repair and sensitivity to PARP inhibitors. Mol. Cell 2011, 41, 210-220. [CrossRef]

153. Yuan, S.-S.F.; Chang, H.-L.; Lee, E.Y.-H.P. Ionizing radiation-induced Rad51 nuclear focus formation is cell cycle-regulated and defective in both ATM(-/-) and c-Abl(-/-) cells. Mutat. Res. 2003, 525, 85-92. [CrossRef]

154. Downs, B.; Wang, S.M. Epigenetic changes in BRCA1-mutated familial breast cancer. Cancer Genet. 2015, 208, 237-240. [CrossRef] [PubMed]

155. Chang, S.; Wang, R.-H.; Akagi, K.; Kim, K.-A.; Martin, B.K.; Cavallone, L.; Kathleen Cuningham Foundation Consortium for Research into Familial Breast Cancer (kConFab); Haines, D.C.; Basik, M.; Mai, P.; et al. Tumor suppressor BRCA1 epigenetically controls oncogenic microRNA-155. Nat. Med. 2011, 17, 1275-1282. [CrossRef] [PubMed]

156. Huang, J.-W. MicroRNA-103 and 107 Target RAD51 and RAD51D to Regulate Homologous Recombination and Enhance Cellular Sensitivity to DNA Damaging Agents. Ph.D. Thesis, University of Washington, Seattle, WA, USA, 2013.

157. Song, L.; Dai, T.; Xie, Y.; Wang, C.; Lin, C.; Wu, Z.; Ying, Z.; Wu, J.; Li, M.; Li, J. Up-regulation of miR-1245 by c-myc targets BRCA2 and impairs DNA repair. J. Mol. Cell Biol. 2012, 4, 108-117. [CrossRef] 
158. Yu, V.P.; Koehler, M.; Steinlein, C.; Schmid, M.; Hanakahi, L.A.; van Gool, A.J.; West, S.C.; Venkitaraman, A.R. Gross chromosomal rearrangements and genetic exchange between nonhomologous chromosomes following BRCA2 inactivation. Genes Dev. 2000, 14, 1400-1406. [PubMed]

159. Sy, S.M.H.; Huen, M.S.Y.; Chen, J. PALB2 is an integral component of the BRCA complex required for homologous recombination repair. Proc. Natl. Acad. Sci. USA 2009, 106, 7155-7160. [CrossRef]

160. Ernestos, B.; Nikolaos, P.; Koulis, G.; Eleni, R.; Konstantinos, B.; Alexandra, G.; Michael, K. Increased Chromosomal Radiosensitivity in Women Carrying BRCA1/BRCA2 Mutations Assessed With the G2 Assay. Int. J. Radiat. Oncol. Biol. Phys. 2010, 76, 1199-1205. [CrossRef]

161. Deng, C.-X. BRCA1: Cell cycle checkpoint, genetic instability, DNA damage response and cancer evolution. Nucleic Acids Res. 2006, 34, 1416-1426. [CrossRef]

162. Feng, Z.; Scott, S.P.; Bussen, W.; Sharma, G.G.; Guo, G.; Pandita, T.K.; Powell, S.N. Rad52 inactivation is synthetically lethal with BRCA2 deficiency. Proc. Natl. Acad. Sci. USA 2011, 108, 686-691. [CrossRef]

163. Liang, Z.; Ahn, J.; Guo, D.; Votaw, J.R.; Shim, H. MicroRNA-302 replacement therapy sensitizes breast cancer cells to ionizing radiation. Pharm. Res. 2013, 30, 1008-1016. [CrossRef] [PubMed]

(C) 2020 by the authors. Licensee MDPI, Basel, Switzerland. This article is an open access article distributed under the terms and conditions of the Creative Commons Attribution (CC BY) license (http://creativecommons.org/licenses/by/4.0/). 